\title{
PROBLEMS IN THE SYSTEM ANALYSIS OF SPACE ACTIVITIES IN UKRAINE. ROCKET AND SPACECRAFT DYNAMICS AND CONTROL
}

\author{
Institute of Technical Mechanics \\ of the National Academy of Sciences of U kraine and the State Space Agency of U kraine \\ 15 Leshko-Popel St., Dnipro 49005, Ukraine; e-mail: aalpatov@ukr.net
}

This paper overviews the main research results obtained from 2016 to 2020 at the Department of System Analysis and Control Problems of the Institute of Technical Mechanics of the National Academy of Sciences of Ukraine and the State Space Agency of Ukraine. The overview was prepared using the method of phenomenological analysis. The results of the system analysis of the trends in the use of space technologies in different areas of human activities are presented. Methods of draft space program evaluation and R\&D program formation algorithms are discussed. Research results on the dynamics of spacecraft and components thereof are presented. The dynamics of tethered space systems and microsatellites is considered. Consideration is given to the world's trends in the development of space transportation systems, the features of their development in Ukraine, and the state of the art of the methodological basis of rocket/space hardware design in Ukraine. Recommendations on working out normative documents and lines of their refinement are given.

System analysis methods were considered and found their further development as applied to the space sector. A method of structural-parametric identification was developed for the problem of object simulation with a multidimensional output in the class of beta-autoregressive models, in which autoregrassion weight coefficient ratios are determined based on beta-distribution density functions. On principles of the group data handling method, a regularity criterion was constructed and studied for simulation in the class of beta-autoregressive models in conditions of quasi-repeated observations. Investigations were conducted into the analysis, synthesis, and operation optimization of systems of multilevel, intellectual, and network management under uncertainty. Methodological approaches to the development of symbiotic self-contained aerospace and transport systems were elaborated. A new technology was developed for the construction of surrogate models with the use of approaches on the basis of the synergy of subject field methods and cognitive technologies based on general scientific achievements. Part of the research results has found prectuical use at Yuzhnoye State Design Office.

Keywords system studies, spacecraft, guided rocket, design parameters, trajectory parameters, rocket flight control program, numerical methods of optimization, robust control systems, industrial orbital complexes, Earth remote sensing, tethered systems.

1. Aksenenko A. V., Gursky A. I., Klochkov A. S., Kondratyuk E. A., Senkin V. S., Syutkina-Doronina S. V. Analysis of the trends in the development of the project parameters and basic performance characteristics of missiles for advanced volley fire systems. Space Technology. Missile Armaments. 2020. No. 1. Pp. 13-25. (in Russian). https://doi.org/10.33136/stma2020.01.013

2. Aksenenko A. V., Baranov E. Yu., Gursky A. I., Klochkov A. S., Morozov A. S., Alpatov A. P., Senkin V. S., Syutkina-Doronina S. V. Methodology for the initial design stage optimization of the design parameters, trajectory parameters, and flight control programs of a missile. Space Technology. Missile Armaments. 2018. No. 2 (116). Pp. 101-116. (in Russian). https://doi.org/10.33136/stma2018.02.101

3. Alpatov A. P., Maslova A. I., Khoroshilylov S. V. Contactless Removal of Space Debris with an Ion Beam. Dynamics and Control. Saarbrucken: Lambert Academic Publishing, 2018. 339 pp. (in Russian).

4. Alpatov A. P., Marchenko V. T., Khorolskyi P. P., Sazina N. P., Zhukova L. H. On a methodological approach to the problem of quantitative risk assessment for space hardware development projects (Part I). Teh. Meh. 2018. No. 1. Pp. 84-96. (in Russian). https://doi.org/10.15407/itm2018.01.084

5. Alpatov A. P., Palii O. S., Skorik O. D. The development of structural design and the selection of design parameters of aerodynamic systems for deorbiting upper-stage rocket launcher. Sci. Innov. 2017. V. 13. No. 4. Pp. 29-39.

https://doi.org/10.15407/scine13.04.029 
6. Alpatov A. P., Goldstein Yu. M. Ballistic analysis of orbits distribution of spacecraft for different functional missions. Teh. Meh. 2017. No. 2. Pp. 33-40. (in Russian).

https://doi.org/10.15407/itm2017.02.033

7. Alpatov A. P., Holdshtein Yu. M. Choice of orbits for space debris utilization. Teh. Meh. 2019. No. 2. Pp. 5-15. (in Russian). https://doi.org/10.15407/itm2019.02.005

8. Alpatov A. P., Holdshtein Yu. M. Methods of orbit clustering of serviced spacecraft. 2019. No. 3. Pp. 91-98. (in Russian). https://doi.org/10.34185/1562-9945-3-122-2019-11

9. Alpatov A. P., Holdshtein Yu. M. On the choice of an optimum on-orbit servicing route. Teh. Meh. 2019. No. 4. Pp. 21-28. (in Russian). https://doi.org/10.15407/itm2019.04.021

10. Alpatov A. P., Svorobin D. S., Skoryk O. D. System for contactless removal of space debris from near-earth orbits using aerodynamic compensator. Teh. Meh. 2016. No. 3. Pp. 51-56. (in Ukrainian).

11. Astapenko V. N., Marchenko V. T., Sazina N. P., Khorolsky P. P. Assessment of demand of national market for information on Earth remote sensing. Teh. Meh. 2016. No. 1. Pp. 60-73. (in Russian).

12. Astapenko V. N., Marchenko V. T., Sazina N. P., Khorolsky P. P. Analysis of capabilities of national information market for remote sensing at high resolution as to 2015. Teh. Meh. 2016. No. 3. Pp. 68-76. (in Russian)

13. Volosheniuk O. L. Global trends in the development of low-orbit space systems for optoelectronic Earth observation. Teh. Meh. 2020. No. 3. Pp. 39-53. (in Ukrainian).

https://doi.org/10.15407/itm2020.03.039

14. Holdshtein Yu. M. On the choice of a parking orbit for a service spacecraft. Teh. Meh. 2020. No. 3. Pp. 30-38. (in Ukrainian). https://doi.org/10.15407/itm2020.03.030

15. Degtyarev A. V., Kashanov A. E., Siutkina S. V. On the choice of priority variants of rocket/space complex modernization. Teh. Meh. 2012. No. 2. Pp. 94-105. (in Russian).

16. Ukrainian Patent Application No. a202007504, IPC B 64 G 1/62. Device for space debris removal from near-Earth orbits. Alpatov A. P., Paliy O. S., Lapkhanov E. O. a202007504 ; filed on November 24, 2020. (in Ukrainian).

17. Ukrainian Patent Application No. a202007505, IPC B 64 G 1/62. Device for spent spacecraft removal from low Earth orbits. Alpatov A. P., Paliy O. S., Lapkhanov E. O. a202007505; filed on November 24, 2020. (in Ukrainian).

18. Ukrainian Patent Application No. 201907947, IPC B 64 G 1/62. Device for shortening the orbit life of space objects in low Earth orbits. Alpatov A. P., Paliy O. S., Lapkhanov E. O. 201907947 ; filed on July 11, 2019. (in Ukrainian).

19. Lapkhanov E. O. Features of the use of magnetic controls in a coarse stabilization of spacecraft with aeromagnetic deorbit systems. Teh. Meh. 2020. No.1. Pp. 56-66. (in Ukrainian). https://doi.org/10.15407/itm2020.01.056

20. Lapkhanov E. O. Features of the development of means for spacecraft removal from near-earth operational orbits. Teh. Meh. 2019. No. 2. Pp. 16-30. (in Ukrainian). https://doi.org/10.15407/itm2019.02.016 
21. Marchenko V. T., Sazina N. P., Khorolskyi P. P., Voznenko A. A. Model for calculating the expected cost of new rocket hardware development with account for uncertainty factors. Teh. Meh. 2018. No. 2. Pp. 30-43. (in Russian).

https://doi.org/10.15407/itm2018.02.030

22. Marchenko V. T., Syutkina-Doronina S. V., Sazina N. P. On the method of simulation of uncertainties of technical and economical data for problems of evaluation of research projects. Teh. Meh. 2016. No. 2. Pp. 137-146. (in Russian).

23. Marchenko V. T., Sazina N. P., Khorolskyi P. P., Zhukova L. H. Algorithm to calculate the technical level of a geostationary satellite communication system. Teh. Meh. 2020. No. 1. Pp. 76-90. (in Russian).

https://doi.org/10.15407/itm2020.01.076

24. Marchenko V. T., Sazina N. P., Khorolskyi P. P., Chernetska N. Ya. Analysis of the trends in the development of Earth remote sensing means. Teh. Meh. 2020. No. 2. Pp. 47-56. (in Ukrainian). https://doi.org/10.15407/itm2020.02.047

25. Marchenko V. T., Khorolskyi P. P., Sazina N. P. Analysis of possible ways for Ukraine to enter the international scene of Earth remote sensing. Teh. Meh. 2019. No. 1. Pp. 107-111. (in Russian). https://doi.org/10.15407/itm2019.01.107

26. Petlyak E. A., Marchenko V. T. About one of the approaches to the assessment of the technical level of geostationary communication satellites. Space Sci. \& Technol. 2020. V. 26. No. 5. Pp. 5-14. (in Ukrainian).

https://doi.org/10.15407/knit2020.05.005

27. Marchenko V. T., Petliak E. P., Sazina N. P., Khorolskyi P. P. Quantitative assessment of the technical level of space systems of earth remote sensing and geostationary satellite communication systems Teh. Meh. 2019. No. 4. Pp. 92-106. (in Russian).

https://doi.org/10.15407/itm2019.04.092

28. Marchenko V. T., Petlyak Ye. P., Sazina N. P., Khorolsky P. P. New method of engineering evaluation of spacecraft for earth remote sensing. Teh. Meh. 2017. No. 2. Pp. 41-50. (in Russian) https://doi.org/10.15407/itm2017.02.041

29. Marchenko V. T., Khorolskyi P. P., Sazina N. P., Zhukova L. H. Algorithm to assess the technical level of Earth remote sensing spacecraft. Teh. Meh. 2017. No. 4. Pp. 41-48. (in Russian). https://doi.org/10.15407/itm2017.04.041

30. Maslova A. I., Pirozhenko A. V. Orbit changes under the small constant deceleration. Kosm. Nauka Tehnol. 2016. V. 22. No. 6. Pp. 20-25. (in Russian). https://doi.org/10.15407/knit2016.06.020

31. Maslova A. I. Estimation of the possible atmospheric density for different orbital flight conditions. Teh. Meh. 2019. No. 3. Pp. 54-65. (in Russian) https://doi.org/10.15407/itm2019.03.054

32 Maslova A. I., Mischenko A. V., Pirozhenko A. V., Khramov D. A. Research of dynamic regularities of electrodynamic space tethered system as a possible highly efficient passive deorbit systems for space debris at the low earth orbits. Kosm. Nauka Tehnol. 2015. V. 21. No. 1. Pp. 20-24. (in Russian). https://doi.org/10.15407/knit2015.01.020

33. Mischenko A. V., Pirozhenko A. V. On determining the design parameters of an electrodynamic space tethered system. Teh. Meh. 2020. No. 1. Pp. 19-30. (in Russian) https://doi.org/10.15407/itm2020.01.019

34. Mishchenko O. V. On the determination of the tether length for an experimental electrodynamic system. Teh. Meh. 2017. No. 4. Pp. 55-63. (in Russian).

https://doi.org/10.15407/itm2017.04.055 
35. Ukrainian Patent for Invention No. UA121460C2, IPC7 B64G 1/24, B64G 1/62. Method for contactless space debris removal from near-Earth orbits using an aerodynamic compensator. Alpatov A. P., Svorobin D. S., Skoryk O. D. 201607424; filed on July 7, 2016, published on June 10, 2020, Bulletin No. 11. 10 pp. (in Ukrainian).

36. Pirozhenko A. V., Maslova A. I., Vasilyev V. V. About the influence of second zonal harmonic on the motion of satellite in almost circular orbits. Space Sci. \& Technol. 2019. V. 25. No. 2. Pp. 3-14. (in Russian).

https://doi.org/10.15407/knit2019.02.003

37. Pirozhenko A. V., Mischenko A. V. Small experimental electrodynamic space tether system. Electrical model. Space Sci. \& Technol. 2018. V. 24. No. 3. Pp. 3-10. (in Russian). https://doi.org/10.15407/knit2018.03.003

38. Pirozhenko A. V., Maslova A. I., Mischenko A. V., Khramov D. A., Voloshenjuk O. L. Project of a small experimental electrodynamic space tether system. Space Sci. \& Technol. 2018. V. 24. No. 2. Pp. 3-11. (in Russian). https://doi.org/10.15407/knit2018.03.003

39. Prokopchuk Yu. A. Intuition: Essay of Formal Study. Dnipro: GVUZ "PGASA", 2021. 276 pp. (in Russian).

40. Prokopchuk Yu. A. Sketch of a Formal Creativity Theory. Dnipro: GVUZ "PGASA", 2017. 452 pp. (in Russian).

41. Savchuk O. P., Fokov A. A. Non-cooperative object parameter determinatin in orbital service tasks. Teh. Meh. 2018. No. 4. Pp. 30-45. (in Russian). https://doi.org/10.15407/itm2018.04.030

42. Sarychev A. P. Algorithm of optimal regressor set search in the vector regression problem. System Technologies. 2016. No. 3. Pp. 14-24. (in Russian).

43. Sarychev A. P. Classification of the states of object, which functioning is described by onedimensional autoregresion. System Technologies. 2019. No. 5. Pp. 61-76. (in Russian).

44. Sarychev O. P. Classification of the state of a dynamic system whose functioning is described by a vector autoregression. System Technologies. 2019. No. 4. Pp. 131-154. (in Russian) https://doi.org/10.34185/1562-9945-4-123-2019-14

45. Sarychev A. P. The linear autoregression with random coefficients based on the group method of data handling in conditions of the quasirepeated observations. Control Systems and Computers. 2016. No. 1. Pp. 3-15. (in Russian). https://doi.org/10.15407/usim.2016.01.003

46. Sarychev O. P., Perviy B. A. Models of space object motion based on time series of TLEelements. Teh. Meh. 2021. No. 1. Pp. 16-24. (in Ukrainian). https://doi.org/10.15407/itm2021.01.051

47. Sarychev A. P. Simulation in the class of systems of autoregressive equations with random coefficients under structural uncertainty. System Technologies of Complex Process Simulation: A. I. Mikhalev (Ed.). Dnipro: NMAU-ICC "System Technologies", 2016. Pp. 463-499. (in Russian).

48. Svorobin D. S., Fokov A. A., Khoroshylov S. V. Feasibility analysis of aerodynamic compensator application in noncontact space debris removal. Aerospace Engineering and Technology. 2018. No. 6. Pp. 4-11. (in Russian).

49. Senkin V. S., Syutkina-Doronina S. V. Studies of effects of variations in parameters of controlled rocket object on flying range. Teh. Meh. 2016. No. 4. Pp. 35-49. (in Russian) 
50. Senkin V. S., Syutkina-Doronina S. V. Study of sensitivity of the target functional to variations of the project parameters of the controlled rocket. Aerospace Engineering and Technology. 2016. No. 3. Pp. 9-17. (in Russian).

51. Senkin V. S., Syutkina-Doronina S. V. On the choice of methods used in the optimization of rocket design parameters and control programs. Teh. Meh. 2019. No. 1. Pp. 3-17. (in Russian). https://doi.org/10.15407/itm2019.01.038

52. Senkin V. S., Syutkina-Doronina S. V. Combined use of random search methods and gradient methods in the optimization of rocket design parameters and control programs. Teh. Meh. 2018. No. 2. Pp. 44-59. (in Russian).

https://doi.org/10.15407/itm2018.02.044

53. Syutkina S. V. Mathematical model for determining the admissible error range for the launch vehicle on launch pad positioning parameters. Teh. Meh. 2013. No. 2. Pp. 26-35. (in Russian).

54. Syutkina-Doronina S. V. Problem of the optimization of the design parameters and control programs of the controlled rocket with solid propellant rocket engine. Aerospace Engineering and Technology. 2017. No. 2 (137). Pp. 44-59. (in Russian).

55. Tarasov S. V., Fokov A. A. Model problems for class of systems for mutual positioning spacecraft and payload. Teh. Meh. 2017. No. 2. Pp. 20-32. (in Russian). https://doi.org/10.15407/itm2017.02.020

56. Fokov A. A., Khoroshilov S. V. Validation of a simplified method to calculate the force exerted by an electojet engine plume on an orbital object, Aerospace Engineering and Technology. 2016. No. 2 (129). Pp. 55-66. (in Russian).

57. Fokov A. A., Savchuk O. P. Algorithms of the operation of a self-contained system for slowing down the rotation of a non-cooperative object of on-orbit servicing. Teh. Meh. 2019. No. 4. Pp. 44-58. (in Russian).

https://doi.org/10.15407/itm2019.04.044

58. Fokov A. A., Khoroshylov S. V., Svorobin D. S. Analysis of the advantages of an aerodynamic compensator in contactless space debris removal. Teh. Meh. 2020. No. 4. Pp. 55-64. (in Ukrainian). https://doi.org/10.15407/itm2020.04.055

59. Fokov A. A., Khoroshylov S. V., Svorobin, D. S. Out-of-plane relative motion of a spacecraft with an aerodynamic compensator during contactless space debris removal. Space Sci. \& Technol. 2021 V. 27. No. 2 (129). Pp. 15-27. (in Ukrainian).

60. Khoroshylov S. V. The algorithm to control the in-plane relative motion of a spacecraft for contactless space debris removal. Space Sci. \& Technol. 2019. V. 25. No. 1. Pp. 14-26. (in Russian). https://doi.org/10.15407/scine14.04.005

61. Khoroshylov S. V. Analysis of the robustness of the system to control the relative motion of an ion beam shepherd. Teh. Meh. 2018. No. 1. Pp. 48-58. (in Russian).

https://doi.org/10.15407/itm2018.01.048

62. Khoroshilov S. V. Synthesis of robust controller for ion beam shepherd control system. Teh. Meh. 2017. No. 1. Pp. 26-39. (in Russian).

https://doi.org/10.15407/itm2017.01.026

63. Ipatov A. P., Holdstein Y. M. On the choice of ballistic parameters of the orbital service device.

Teh. Meh. 2019. No. 1. Pp. 25-37.

https://doi.org/10.15407/itm2019.01.025

64. Alpatov A., Khoroshylov S., Lapkhanov E. Synthesizing an algorithm to control the angular motion of spacecraft equipped with an aeromagnetic deorbiting system. Eastern-European Journal of Enterprise Technologies. 2020. V. 1. No. 5(103). Pp. 37-46. 
https://doi.org/10.15587/1729-4061.2020.192813

65. Alpatov A., Lapkhanov E. The use of mobile control methods for stabilization of a spacecraft with aeromagnetic deorbiting system. System Technologies. 2019. No. 6. Pp. 41-54. https://doi.org/10.34185/1562-9945-6-125-2019-04

66. Alpatov A. P., Khoroshylov S. V., Maslova A. I. ontactless de-orbiting of space debris by the ion beam. Dynamics and Control. yiv: Akademperiodyka. 2019. 170 pp.

https://doi.org/10.15407/akademperiodyka.383.170

67. Alpatov A., Cichocki F., Fokov A., Khoroshylov S., Merino M., Zakrzhevskii A. Determination of the force transmitted by an ion thruster plasma plume to an orbital object. Acta Astronautica. 2016. No 119. Pp. 241-251.

https://doi.org/10.1016/j.actaastro.2015.11.020

68. Alpatov A., Khoroshylov S., Bombardelli C. Relative control of an ion beam shepherd satellite using the impulse compensation thruster. Acta Astronautica. 2018. V 151. Pp. 543-554. https://doi.org/10.1016/. actaastro.2018.06.056

69. Khoroshylov S. Out-of-plane relative control of an ion beam shepherd satellite using yaw attitude deviations. Acta Astronautica. 2019. V. 164. Pp. 254-261.

https://doi.org/10.1016/j.actaastro.2019.08.016

70. Khoroshylov S. Relative control of an ion beam shepherd satellite in eccentric orbits. Acta Astronautica. 2020. V. 176. Pp. 89-98.

https://doi.org/10.1016/j.actaastro.2020.06.027

71. Khoroshylov S. Relative motion control system of spacecraft for contactless space debris removal. Science and Innovation. 2018. V. 14. No. 4. Pp. 5-16.

https://doi.org/10.15407/scine14.04.005

72. Khoroshylov S., Redka . Relative control of an underactuated spacecraft using reinforcement learning. Teh. Meh. 2020. No. 4. Pp. 43-54. https://doi.org/10.15407/itm2020.04.043

73. Lapkhanov E., Khoroshylov S. Development of the aeromagnetic space debris deorbiting system. Eastern-European Journal of Enterprise Technologies. 2019. V. 5. No. 5(101). Pp. 30-37. https://doi.org/10.15587/1729-4061.2019.179382

74. Nosov P. S., Popovych I. S., Cherniavskyi V. V., Zinchenko S. M., Prokopchuk Y. A., Makarchuk D. V. Automated identification of an operator anticipation on marine transport. Radio Electronics, Computer Science, Control. 2020. No. 3 (54). Pp. 158-172. https://doi.org/10.15588/1607-3274-2020-3-15

75. Perviy B. A. Improving SGP4 orbit propagation. System Technologies. 2019. No. 6. Pp. 76-81. https://doi.org/10.34185/1562-9945-6-125-2019-07

76. Perviy B. A., Sarychev A. P. Influence of the Magnus effect on the spacecraft lifetime. System Technologies. 2018. No. 2. Pp. 20-31.

77. Pirozhenko A., Maslova A., Khramov D., Volosheniuk O., Mischenko A. Development of a new form of equations of disturbed motion of a satellite in nearly circular orbits. Eastern-European Journal of Enterprise Technologies. 2020. V. 4. No. 5 (106). Pp. 70-77. https://doi.org/10.15587/1729-4061.2020.207671

78. Sarychev A. P., Sarycheva L. V. GMDH-based optimal set features determination in discriminant analysis. System Technologies. 2019. No. 6. Pp. 26-40. https://doi.org/10.34185/1562-9945-6-125-2019-03

79. Sarychev O. P., Perviy B. A. Autoregression models of large space debris motion. System 
Technologies. 2020. No. 6. Pp. 137-148.

https://doi.org/10.34185/1562-9945-6-131-2020-12

80. Sarychev O. P., Perviy B. A. Autoregression models of space objects movement represented by TLE elements. System Technologies. 2020. No. 2. Pp. 103-116.

https://doi.org/10.34185/1562-9945-2-127-2020-08

81. Sarychev O. P., Perviy B. A. Optimal regressors search subjected to vector autoregression of unevenly spaced TLE series. System Technologies. 2019. No. 2. Pp. 95-110.

82. Sarychev O. P., Perviy B. A. Revealing changes in the space objects motion described by autoregressive models. System Technologies. 2021. No. 2. Pp. 79-88.

https://doi.org/10.34185/1562-9945-2-133-2021-09

83. Senkin V. S., Syutkina-Doronina S. V. On the issue of choice of the parameter optimization method for a guided missile. Science and Innovation. 2020. V. 16. No. 3. Pp. 50-64.

https://doi.org/10.15407/scine16.03.050

Received on May 31, 2021,

in final form on June 7, 2021 